\title{
Tribal Motivation in Sponsorship : Influence on Sponsor Relationship Development and Corporate Identity
}

\begin{abstract}
Whilst the literature on sponsorship suggests it has evolved from a philanthropic gesture to a strategic tool that mangers leverage to provide sustainable competitive advantage, this paper reports on a study which suggests other motivational factors may be on par with or supersede commercial or altruistic considerations. Drawing on self identification, social identity and tribal marketing literature, the paper explores the concept of tribal support as a motivational factor for sponsorship participation and examines the moderating effect this may have on sponsor-object relationship development and on corporate identity development. Findings show strong sub-cultural, tribal connection and variations in self and social identification among sponsors and demonstrate how sponsorship motivation affects sponsor relationship development, sponsor-event fit, brand association and corporate identity development in complex ways.
\end{abstract}

Keywords: Sponsorship, Tribal Marketing, Social Identity, Self-Identification Theory, subcultural association, motorcycling

Tony Garry, De Montfort University, UK

Anne Broderick, De Montfort University, $\mathrm{UK}^{1}$

Katy Lahiffe, De Montfort University, UK

Paper Submitted to the Journal of Marketing Management

\footnotetext{
${ }^{1}$ All correspondence in connection with this paper should be addressed to A. Broderick, Department of De Montfort University, The Gateway, Leicester, LE1 9BH, Telephone 0116 250 6136. email ambmar@dmu.ac.uk .
} 


\section{Tribal Motivation in Sponsorship : Influence on Sponsor Relationship Development and Corporate Identity}

\section{INTRODUCTION}

The scarcity of research on sponsorship in general (e.g. Cornwell and Maignan, 1998, Teofilou et al, 2007) and the nature of the relationship between sponsor and sponsored in particular (e.g. Dolphin, 2003; Farrelly and Quester, 2003) is conspicuous within the marketing literature. Indeed Olkkonen and Tuominen (2006) suggest that 'the main weakness of previous academic research' (p.66) within the sponsorship field is a lack of underlying theoretical and conceptual foundations on which to base scholarly inquiry. Yet recent thinking proposes that sponsorship has evolved into a 'mainstream component of the marketing mix' (Polonsky and Speed, 2001:1361) to the extent that it is now considered a strategic tool that managers leverage to provide sustainable competitive advantage (e.g. Fahy et al, 2004).

Where there has, in particular, been limited theoretical development is in the link between sponsorship motivation as a moderator of the sponsor relationship and as a contributor to corporate identity development. Drawing on social psychology; in particular, social identity, self identification and tribal marketing literature, (Hogg and Turner, 1985; Hunt et al, 1999; Cova and Cova, 2002), this paper identifies the concept of tribal support as a motivational factor for sponsorship participation and explores the relationship between sub-cultural linkages through sponsorship and corporate identity development. Firstly, a synopsis of the salient literature on sponsorship, social and self-identification, tribalism in marketing and stakeholder orientation and sub-cultural dimensions of corporate identity is offered. Thereafter, the contextual relevance to the motor sport context of this study is evaluated and the research methodology is outlined. Findings from in-depth interviews with key sponsorship decisionmakers at the BSB Motorcycling Championships in the UK, ranging from managing directors, to brand marketing managers to dedicated sponsorship liaison personnel are reported. The extent of tribal connection and degree of social identification in sponsor motivation is outlined, as is the impact on sponsor-object relationships. Implications of findings for the development of successful sponsor relationships and in turn for corporate identity development are then discussed, notably how sponsoring organisations might consider more subtle and sophisticated sponsorship activities that reinforce image transfer between the event and the brand and an evolving corporate identity logic within certain market contexts.

\section{LITERATURE REVIEW}

\section{Sponsorship}

On reviewing the literature related to sponsorship, three strands may be identified (Olkkonen and Tuominen, 2006) - firstly, definitional issues pertaining to the processes and outcomes of sponsorship; secondly communication issues including measurements of effect and effectiveness and finally; managerial issues including the drivers of sponsorship activities. For the purposes of this research, the review of the literature will focus on this latter area. A number of 'drivers of sponsorship' (Dolphin, 2003: 178) may be identified within the literature. These include: exposure seeking (Meenaghan, 1991); brand association (Thwaites et 
al., 1998); attempts to alter public perceptions (Grimes and Meenaghan, 1998); community involvement (Mack, 1999); the creation of goodwill (Meenaghan, 1991); the enhancement of employee motivation (Tripodi, 2001) and corporate philanthropy and altruism (Bennet, 1997). Given the focus of this research, it is particularly important to distinguish between altruistic and other sponsorship drivers. Walliser (2003) distinguishes sponsorship from altruistic activity by focusing on intended exploitation of the association between sponsors and sponsored. Dolphin (2003) suggests that:

'Patronage is based on charity.... but sponsorship activity typically refers to the financial support given by an external organisation to a leisure or sporting activitysupport with a definite commercial objective in mind '( $\mathrm{p} .176)$.

Thus, pure altruism is an 'expression of a person's internal values independent of social or material gain' (Bennet, 1997:87). However, it is posited here that there may be further motivational factors in addition to commercial or altruistic drivers. Social identity and tribal association theory proposes that people will engage in activities to support a particular social community or 'tribe' where that 'tribe' is congruent with their own self definition and identity.

\section{Self Identification and Self-Categorization}

Drawing on social psychology literature, Hunt et al., (1999) define a sports 'fan' as an 'enthusiastic devotee of some particular sports consumptive object' (p. 440). Implicit within this definition is that some level of attachment exists between an object and the individual. This level of attachment is effectively determined by a schema containing perceptions, beliefs and expectations associated with the object (e.g. Hunt et al,1999). This may, in some instances, culminate in self identification with the object thus implying such objects are used by individuals to identify their perceived self to their actual self and indeed to others (e.g. Ball and Tasaki, 1992). Related to this, self-categorization theory suggests that individuals classify themselves into a number of social categories in order to facilitate self-definition within their social environment (Haslam and Turner 1992). This 'oneness or belonging to a group' (Gwinner, 2003:277) may enhance self-esteem, positive social identity and social prestige (Ellemers et al, 1999) and evoke feelings such as 'camaraderie', a sense of 'community' and 'solidarity' (Zillman et al., 1989). Within sporting contexts, a number of classification studies have been conducted which identify levels of personal identification, relevance and resultant social identification (e.g. Gwinner and Swanson, 2003). For example, Real and Mechikoff (1992) identify a category of sports follower distinct from other sports followers whom they term 'deep fans' and who are characterised as having a 'ritual' identification with a sports object as a manifestation of their self and social identification. Hunt et al. (1999) suggest a classification criteria focusing on motivational distinctions which identify five categories of sports followers (temporary fan, local fan, devoted fan, fanatical fan and dysfunctional fan). As one ascends the typology, the more likely an object is to constitute part of an individual's self identity and the greater the significance of an individual's emotional attachment.

\section{Social Identification Theory and Tribal Analogies}

Social identification theory suggests that individuals, in enhancing their self-esteem, (Turner and Hogg, 1985; Ashforth and Mael 1989), seek to identify with groups that have attractive or prestigious public images (Dutton et al.,1994). Through motives of self-continuity (maintaining a consistent social identity-Tajfel and Turner, 1986) or self-enhancement (gaining 
status through group belonging - Ashforth and Mael, 1989), they seek similarity with group behaviour. Perceptions of 'deep' level similarity impact on the degree of social identification an individual may have with pertinent groups (Harrison et al, 1999) and where this results in an intense 'community of emotion or passion' (Cova and Cova, 2002:598), tribal analogies have been drawn. Cova and Cova (2002) define a tribe as "a network of heterogeneous persons linked by a shared passion or emotion" (p. 602). Tribal members are recognised and recognise themselves as members of a group and will often gather and perform ritual acts in public places known as 'anchoring events' (Aubert-Gamet and Cova, 1999). Drawing on parallels with social relationships, Cova (1999) suggests that tribes rely on such anchoring events to sustain their membership, to reaffirm and strengthen the underlying values of the group and to provide a platform to bring together and bond individual members of the tribe. Typical of such events are certain sporting occasions, which may be perceived as tribal anchoring events which provide the opportunity for members of the tribe with sufficient resources to express their emotional attachment through displaying their loyalty and identification to the 'tribe' by contributing to the sponsorship of such events.

\section{Stakeholder Orientation and Sub-cultural Dimensions of Corporate Identity}

Corporate identity is a complex entity, as noted in previous work on seven dimensions of corporate identity by Melewar and Karaosmanoglu (2006); in the six station model of corporate identity developed by Suvatjis and de Chernatony (2005); in the relationship between personal interpretations of identity and corporate reputation noted by Bromley (2001) and in the explanation of how corporate identity relates to corporate image, as noted below:

'The total sum of signs that stands for an organization to its various audiences we call the corporate identity, recognizing, of course, the interplay of interpretations that construct the totality' (Christenson and Askegaard, 2001, p 304, also citing Cheney and Tompkins, 1987).

While Christenson and Askegaard (2001) may reflect a strong semiotic orientation in their examination of corporate identity, they nonetheless capture its holistic nature. More recent studies have examined the close affinity between concepts of corporate identity and corporate branding (Knox and Bickerton, 2003; Kay, 2006) and some commentators (Balmer and Geyser, 2006) have recently argued for a greater integration between multiple concepts such as corporate marketing, corporate identity and corporate branding.

Sponsorship is a decision that is part of the corporate marketing effort and encompasses certain aspects of corporate identity. It is not within the scope of this study to comprehensively review elements of corporate identity; but to focus on the way sponsorship relates to the stakeholder orientation within corporate marketing (Balmer and Geyser, 2006), and to highlight within the research undertaken, the sub-cultural dimensions associated with corporate identity (Melewar and Karaosmanoglu (2006). Balmer and Geyser, (2006, p 733), note a key orientation in corporate marketing towards stakeholders and a key application in addressing present and future stakeholder and societal needs. The stakeholder input into corporate identity is also captured well by Suvjatis and de Chernatony (2005) and by Christensen and Askegaard (2001) when they suggest that we need to 'conceive of organizational identity as symbolic representations of organizations that appeal to many different audiences across formal boundaries'.. (p 304) 
The importance of sub-cultures to corporate identity has been noted by multiple authors, in marketing, it has featured in work by Deal and Kennedy, (1982), Balmer and Wilson, (1998); further refined by Melewar and Karaosmanoglu,(2006). Corporate identity is informed by corporate culture, which is an amalgam of sub-cultures (Knox and Bickerton, 2003), some of these may be historical, as in perceived closeness to the founder, or may be defined through varying professional affiliations between engineers and accountant, while others may link to specific interest groups (Deal and Kennedy, 1982). Reinforcing the idea of multiple identities that might be evident within an overall corporate identity (Pratt and Foreman, 2000, Balmer and Greyser, 2006), sub-cultural influences can become more complex is when they cross organizational boundaries. Christensen and Askegaard (2006), citing Gray, (1986), specifically note that corporate identity is "an interpretation composed of perceptions and impressions of members among both members and non-members of the organization" (2006, p 298). Sponsorship motivations and decision-making reflect the existence of sub-cultures, since such decision-making is non-linear, and in circumstances where there are strong lateral links between the sponsor and external stakeholder group (sponsored), sub-cultural motivations may vary. In the motorcycling context, important stakeholder groups might be 'aficionados' of motorcycling (and motorsports) and may be strongly reflective of an industry identity, noted as important by Melewar and Karaosmanoglu (2006).

\section{SUB-CULTURAL AND TRIBAL ASSOCIATIONS IN THE RESEARCH CONTEXT}

Previous research has recognised motorcyclists as having a 'shared cultural understanding' and a 'dominant community ideology' implying tribal connotations and culminating in congregations at 'contemporary motorcyclist enclaves' (Haigh and Crowther, 2005:559-60) such as race events. One such event is the British Super bike (BSB) Championship. The BSB Championship is the leading UK domestic production motorcycle series, it attracts participants from leading motorcycle manufacturers around the world. Recent years have seen an exponential growth in it's popularity. As a result, the BSB Championship is an increasingly attractive proposition to potential sponsors as it enjoys increasing levels of exposure, is relatively low in 'sponsorship clutter' (Fahy et al., 2004) and is still comparatively affordable compared to other motor sports events. The sport has witnessed increasing on-track attendance and media coverage; associated with this has been a marked increase in sponsor support from larger, often global organisations dominated by marketing professionals. The psychological mindset of such personnel may be to view sponsorship purely as a commercial investment (Walliser, 2003) from which multiple commercial returns are sought (Abratt et al., 1987). Yet, the level of cultural connection and involvement of some manufacturers with the sport suggests sponsorship action in BSB championships may incorporate social identification with a prestigious group (Dutton et al, 1994); a capacity to self-categorize as a fan of the sport (Ellemers et al, 1999; Hunt et al, 1999) and potentially a tribal connection may exist (Cova and Cova, 2002). If social identification or tribal connection is a driver of the sponsorship decision in this context, we need to ask in what way is this manifested, how does it affect the sponsorobject relationship or relate to corporate identity development of the sponsor.

\section{RESEARCH METHODOLOGY}

The primary research undertaken had two main objectives: a) to clarify the degree to which social identification and the concept of tribal support is a motivational factor for sponsorship participation and b) to explore the moderating effect this may have on sponsor-sponsored 
relationship expectations within the British Super Bike Championship. The phenomenological nature of the study (i.e. the focus on social and self identification of respondents) suggested a qualitative approach to be appropriate as it accommodates 'deep' and 'rich' insights (Geertz, 1973), involves observation and recording of complex human behaviour and social systems (e.g. Feyerabend, 1981; Popper, 1965) and is useful for examining developing social processes. In-depth interviews (of between 45 and 60 minutes) were undertaken, which permitted probing (Spiggle, 1994), with a focus on contextual understanding (Strauss and Corbin, 1990) and a purposive sampling approach (Saunders et al, 2007) was followed. A total of nine respondents were selected - encompassing perspectives from sponsors with different roles in the BSB Championship; sufficient to capture the data necessary to achieve the objectives of the research (McCracken, 1998). A discussion guide was developed, used as a starting point from which respondents could elaborate on their own experience and motivations for sponsorship. Interviews were taped and transcribed, with initial open and axial coding (Saunders, 2007; Goulding, 2001) to facilitate subsequent content analysis (Spiggle, 1994). A reiterative approach was adopted (Remenyi et al., 1998) thus enabling the findings of one interview to inform the next as new insights and evidence emerged.

\section{RESEARCH FINDINGS}

Findings are reported in three areas: a) the extent of tribal connection among sponsors and variations in social identification; b) how variation in sponsor motivation influences relationships with sponsor-objects and c) how this may reflect sub-cultural elements in corporate identity development

\section{Variation in social identification and extent of tribal connection among sponsors}

A proportion of sponsors have a prior interest in motorcycle racing. Similarly, most racing teams are established by ex-racers and/or enthusiasts. Consequently, the extent of emotional attachment and associated 'sharing of passion' for the sport varied among sponsors. (as expected from Real and Mechikoff, (1992). Where sponsors had particular corporate communication objectives for sponsorship, it was recognised that there was some 'disconnection' with the tribe, (Cova and Cova, 2002), as noted in the following comment :

'It's not something I consider important - the two parties are totally different... There can't be more than twenty days a year when we're together...' (R1).

This indicates a distinct self-categorization away from the sponsored (rider) group (Turner, 1987). Similarly, sponsors cited purely commercial reasons for sponsorship activities; one showed a level of disconnection with the sponsor- object by using an agent to act for them:

"The decisions are primarily on a commercial basis, almost exclusively... My time is valuable and I don't want to be spending my time [arranging] race sponsorship. It's not an important part of what we do... I can make a lot of money doing other things" [R5].

Despite the focus on commercial bottom line objectives, there were, nonetheless, among other respondents, clear implicit indications of tribal connectivity and support with the term 'esprit de corps' and family relational metaphors being used to emphasise the nature of the relationship.(in line with Aubert-Gamet and Cova, 1992). For example, one sponsor states: 
"It's the emotional involvement...I haven't got emotional relationships with brothers or sisters but imagine that it's like they are sons or brothers....it's completely different to a commercial relationship!' (R4).

Thus, the corporate bottom line is a motivation that is secondary to a tribal self-extension, with a strong bond of identification (Bhattarachya et al, 2005). Sponsors who were ex-racers themselves recognised the inherent dangers of the sport; this manifested itself in mutual understanding and empathy, with clear self-identification (Brewer et al, 1996). The extent of emotional attachment could impinge on rational sponsorship decision making, shown below:

"In motorcycle sport....it ends up becoming personal. Everyone sets out their stall as to what the company can afford ... but you'll always get a case... especially with sponsors that have been coming to every meeting for years... that they get so personally and emotionally involved that you end up..... if the bike gets crashed...sponsors will always pull something out of the hat ... its from rider to rider and not just sponsor to rider' (R4).

A clear sub-cultural belonging is expressed here, (Gwinner, 2003). The reference to those coming to every meeting is also reflective of a self-continuity approach to social identification. (as noted in Turner, 1987). The bond with the sponsored 'riders' is more binding than their commitment to specific corporate identity objectives.

\section{Motivation and sponsor-object relationship development}

Formality -Informality of Relationship

One key finding was the degree of informality that was noted in the sponsor relationships, principally noted in terms of communications. Respondents describe their communications as close, informal and regular, even friendly, citing openness and honesty as very important and a conduit to building trust and commitment.

'...The whole relationship building process is communication... The better you communicate, the more you get to know them, and so the more you trust them. And if you talk to people you can sort out problems and get what you want which has to make you more loyal...' (R4)

The quality of the communications is considered very important, central, and allows the accomplishment of, for example, cooperation, reassurance, resolution of conflict. communications are seen as an input and an outcome in relationships:

'The quality of the communications is the most important thing. If you can have quality communications and keep it informal it actually saves a lot of work.' (R5)

'Good communications are both vital and central to a good relationship. Everything depends on them. Also, a good relationship facilitates better communications too...' (R7)

Where the degree of formality -informality was particularly evident was in the instances of functional conflict that emerged in the sponsor relationship. Perceptions of this varied across respondents - some held different views on what constituted 'interference', as noted below:

'I don't think it is our right or duty or anything to start interfering with what the race team wants to do so the function conflict will be quite limited. '(R1) 
Sponsor Relationship Trust Building

On the other hand, a number of respondents commented on trust being important to resolving working relationships and saw differences as a normal part of that :

'I'd say that I'd trust someone more when a disagreement is sorted out and I trust someone I assume we can sort out any new problems. After all that's how you get to know what someone wants...' (R7)

'Conflict brings things to the surface. It identifies, clarifies strengths and weaknesses. If it's dealt with to a mutually beneficial outcome it can only be good.' (R8)

In this comment, we see strong emphasis on mutuality and reciprocity - and this was reflected in comments on trust by many respondents. Respondents saw trust as essential for commitment success in sponsorship relationship, judging it to be as important as in other commercial relationships:

'It's on or off as far as I am concerned-if that trust is breached that's the end of it.' (R2)

'Trust is more important... many things you buy you can take back or have remade! You can't take back a seasons racing!' (R7)

Insert Table 1 > >>>>>>>>>>>>>>

Some respondents highlighted how the trust developed reduces uncertainty in decision making: 'All decisions are based on trust... if I am told something I take it as being true. What this means I have a lot more time to develop things properly, because I'm not having to go around auditing and checking!' (R2)

This is reinforced by comments that respondents made at the outset in their general sponsorship philosophy- all respondents felt they had long-term commitment to their sponsorship relationships and believed most, if not all, benefits would be awarded over the long-term (See Table 2). However, for a relationship to work communications alone may be inadequate. R8 highlights an example of where the communications couldn't overcome a lack of shared values and cooperation.

'When our sponsorship relationships collapsed communications didn't overcome the conflict as the team didn't share our mission and objectives - communications alone proved insufficient' (R8)

This pattern is also reinforced in the citing by respondents of degree of cooperation as significant to degree of success in sponsor relationships, both as an antecedent and outcome of relationship commitment and trust:

'It's vital on both sides... I need to trust the rider and be in an established partnership already in order to cooperate.' (R7)

'Relationships are about give and take. I'd only compromise if I trust them and am in it for the running... if a partner refuses to cooperate I would lose trust and possibly my 
commitment... commitment and trust are reciprocal. If my partner is willing to cooperate this displays their commitment and trust... '(R8)

These patterns indicate some moderating effect of the degree of formality- formality on the duration of the sponsor relationship and, in the medium term on corporate reputation of sponsors. For respondents $2,4,7,8$, the reputation of the sponsor among the motorcycling racing stakeholders and the public was critical but in different ways - For R4, it was critical to be personable, open, respected by riders and financial backers, in order to forge good rider sponsorships in the future. For R4, R7 and R7, all of whom had formerly been riders or part of competing teams, in emphasizing the casual, informal nature of the sponsor activities, they define themselves as firmly belonging to the tribe. In contrast, R1, R5 and R6 were more globally ambitious, sought more specific outcomes and all evaluated the sponsorship in more formal terms (R1 - a return in 0-18 months), R3- a four year, annually reviewed agreement and R6 - whether to continue formal agreement with Honda). See Table 2.

\section{Insert Table 2 here $>>>>>>>>>>>>>$}

From the table, it is interesting that respondent 7 and 8, who articulate the significance of trust, commitment and cooperation to sponsor relationship success most strongly were committed in a philanthropic way to sponsorship (demonstrating strong tribal associations with motorcycling). There is clearly a strong sponsor-event fit for these respondents but associated with that are expectations in terms of mutuality and trust-building within that relationship.

\section{Impact of level of Tribal and Social Identification on Sponsorship Measurement}

Despite the informality of relationships, clear commitments/ objectives were set by respondents, as noted in Table 2 above, and below: :

'Once we have made a decision to do something for a year we will definitely stick to it... our word is our bond.' (R1).

Thus, at one level a commercial orientated trust exists in terms of 'promise fulfilment' (Wetzel et al., 1998). However, at another level, a benevolent trust comprising of an 'interest in the partner's welfare' (Geyskens and Steenkamp, 1995) was also identified, typically in sponsorships where less specific corporate marketing outcomes were sought. Such sponsors would often initiate and construct social bonds with riders other than those they sponsor primarily to reinforce the 'community of emotion or passion' (Bromberger, 1998). As one respondent states:

I try to firstly have a good relationship with everyone, a friendly relationship.. This is very, very important ... being an ex-rider' (R3).

This provides evidence of the level of social identification of some sponsors (Hogg and Turner, 1985). There was even a sense that the social identification was primary and the commercial justification secondary, as noted below :

When commitment is emotionally-based, you tend to look for the rationale that supports it from a business point of view (R2)

Where this level of social identification (or not) was pertinent was in sponsor expectations. For sponsors with specific corporate marketing objectives (e.g. strong brand identification at the 
event), their perception of the sponsor-object was sometimes low- the sponsored were often perceived as lacking the interpersonal skills and/or motivation required to support the aspirations of sponsors. One respondent comments:

"You ultimately feel taken for granted....just money bags...I gave and they took...and yet the team [the sponsored object] said they were doing what they were expected to do...to ride.... without tenting and trees [corporate hospitality]' (R8).

This highlights a lack of congruence between the logic of what the sponsorship is expected to achieve (a visible corporate identity in sense of Aaker, (2004) and the internal subculture of the sponsored team. The bond of identification (Bhattarachya et al, 2005) is low and it demonstrates some of the impact of the power balance in relationships (Greyser, 1997). This power balance was elaborated further by another respondent:

"The classic thing, particularly in sport, is that people who are looking for sponsorship are obsessed with the sport...... and have no grasp at all of what we want out of it.... I think $X$ have a very clear understanding of what we want and are mindful that in order to get renewed sponsorship they have to deliver that as far as they can " (R2)

This may reflect some of Balmer and Geyser's (2006) argument that corporate marketing relationships are 'expectational'. (as distinct from manipulative, service and transactional, noted by Geyser, 1997). Clearly, some trust has been established here, a level of social identification is present (albeit that specific self-enhancement for sponsor is sought) between the two parties, and some corporate marketing goals are jointly understood. In contrast, certain sponsors articulated less explicit marketing goals and did not see participation in the corporate hospitality process to be a priority. As one sponsor states:

'I don't think that my loyalty to my riders is different because of their ability to promote themselves. They aren't asked to promote me anyway so marketing isn't an issue...I'd rather they focus on riding' (R7).

The use of the first person in this commentary shows clear and strong evidence of 'deep' similarity and a close identification with riders. (in line with Harrison et al, 1999). Thus, in the cases noted here, sponsor motivation derived from sub-cultural identification or tribal connection (Cova, 1999) has a direct impact on sponsor expectations of the sponsor-object.

\section{CONCLUSION AND MARKETING IMPLICATIONS}

Sponsorship motivation has historically been perceived as either 'a philanthropic gesture' (Hoek and Gendall, 2003:1) or a strategic marketing tool (e.g. Fahy et al., 2004). However, in this study, motivations of sponsors showed greater variation than previously noted (Polonsky and Speed, 2001; Dolphin, 2003) and a greater complexity in how sponsorship related to corporate identity development (involving a range of dimensions, as noted by Melewar and Karaosmanoglu, 2006). This extends previous work on sponsorship (Farrelly and Quester, 2003), in two areas: firstly, in this research, the tribal connection or disconnection; the degree of social identification among certain sponsors were illustrations that motivations for sports sponsorship are varied and complex; and that varied motivations of sponsors influence the expectations and nature of the sponsor-object relationship. Marketing implications are threefold: b) sponsor-event fit and the leveraging of brand association through image transfer 
b) how tribal motivations match an 'interpretation' logic in corporate branding and c) how tribal sponsorship motivations tap into sub-cultural dimensions of corporate identity.

\section{Tribal Motivation and Sponsor-Event Fit - Leveraging Brand Association}

This study has generated some important insights into the sponsor-event fit, regarded as important in past sponsorship studies (notably, D'Astous and Bitz, 995 and Otker and Hayes, 1987, Speed and Thompson, 2000), who have suggested that a strong synergy between sponsor and event leads to more positive outcomes. However, past studies have identified less the nature of that fit and much of this is down to limited conceptualization of brand image transfer, as noted by Smith (2004). If, as Kay (2006) and Aaker, (2004) argue, brand equity is built over time; if, as Smith (2004) suggests, there are external antecedents (such as domain of sponsorship) and internal antecedents (such as brand knowledge) to brand image transfer; then the achievement of sponsor-event fit is quite complex.

This study, in highlighting tribal identification motives within sports sponsorship, has demonstrated the way socially-based motives may generate a strong sponsor-event fit but may equally encourage behaviours such as increased mutuality and reciprocity in decision-making. Both of these elements (strong sponsor-event fit and mutual decision-making) are conducive to commitment and long-term successful sponsor relationships.

\section{Tribal Motivation - matching an 'Interpretation' logic in corporate branding}

Kay (2006) suggests that corporate brands acquire power in different ways; contrasting 'product' logic (product identification), with the logic of 'consistency' (consistency of brand positioning). While sponsorship decisions have, latterly, been subject to a clear strategic 'logic', (Fahy et al, 2004), this logic has, arguably, been largely implemented as part of marketing communications approaches, or, on the basis of 'controlled corporate communication' (Melewar and Karosmanoglu, 2006). Moingeon and Ramanantsoa, (1997) see value in less controlled corporate communication, which may suggest positive values to external stakeholders. Within key stakeholder groups there may be members dynamically constructing the corporate brand identity; there may also be strong emotional responses from stakeholders (Topalian, 2003), seen as important to corporate image by Balmer and Greyser, (2006) and to sponsorship commitment by Lings and Owen (2007).

Sponsorship, in contexts such as motorcycling, may need to embrace sub-cultural linkages, which Melewar and Karaosmanoglu, (2006) see as fundamental to corporate identity. In such an approach, sponsorship is less about product identification or reinforcement of brand consistency; but encompasses a logic that is about encouraging corporate brand 'Interpretation' with key internal-external member groups, which may even stretch to brand negotiation (as noted by Gregory, 2007). Within these market contexts, sponsorship decisions may contribute more to the continuous evolving definition of the corporate brand, through brand perceptions that are actively generated across internal-external sub-cultural boundaries.

\section{Tribal Motivation - tapping into sub-cultural elements of corporate identity development}

Findings in this study have shown that some decision-makers engaged in sponsorship in the motorcycling sector are socially identifying with a prestigious group (in line with Hogg and Turner, 1988; Dutton et al, 1994) through strong tribal association (Cova and Cova, 2002). 
While the sponsor-object relationship ostensibly focuses on marketing objectives; in this context, an equally important 'sought' outcome for some sponsors is the social association with the riders and the BSB Championship. In this sense, there is some divergence in the sponsor relationship focus and in corporate identity development - one outcome is reinforcement of company visual identity and corporate brand identification (noted by Kay, 2006) within the motorcycling industry and its publics. An alternative outcome is an enduring establishment of corporate credibility through a social association and sub-cultural connection with a key stakeholder group (Deal and Kennedy, 1982; Christensen and Askegaard, 2001) - in this case, the motorcycling teams, riders and 'aficionados' of motorcycling. The maintenance of this social (tribal) credibility was clearly an underlying motivation for some respondents.

Organizations need to consider more subtle and sophisticated sponsorship activities such as identifying, supporting and even 'infiltrating' (Cova and Cova, 2002) pertinent tribes to the extent that 'the company is not simply an economic actor adapting to the market, but a social actor relating to the societal context' (Badot et al., 1993:51). Sub-cultural connections arising among organizational members and their own social association or identification with key stakeholder groups exist in certain market contexts - these connections may, in some market contexts be determinant of enduring sponsorship. From this study, it was evident that sponsorship motivation that derives from sub-cultural connections can a) act as a cementing force in establishing mutuality and commitment over time in sponsor relationships; b) they may reinforce bonding, image transfer and indeed negotiation of the sponsor brand (in line with the work of Gregory, 2007); and c) they can act effectively as a fusion of corporate identity - both within and external to the company.

Future research might examine these issues further by longitudinal research over a three to five year period or; alternatively, a cross-sectional study that would examine event sponsorship in domains other than motorcycling and look at the moderating effect of motivation (tribal, strategic) on actual behaviour (mutuality of decision-making, trust etc) on perceived sponsorevent fit, on perceived sponsor relationship success (duration, significance, benefits etc) and on perceived corporate identity development

\section{References}

Aaker D., (2004), 'Leveraging the corporate brand', California Management Review, Vol 41, No s, Spring, pp. 102-124.

Abratt, R., Clayton, B. and Pit, L. (1987), 'Corporate Objectives in Sports

Sponsorship', International Journal of Advertising, Vol. 6, No. 4, pp 299-311.

Arthur, D., Dolan, G. and Cole, M. (1998), 'The Benefits of sponsorship Success: An analysis of the relationship between Television Exposure and the Position of a Motorcycle Rider', The Cyber-Journal of Sport Marketing, Volume 2, No. 2, pp. 1-15.

Ashforth, B. and Mael, F. (1989), 'Social Identity Theory and the Organisation', Academy of Management Review, Vol. 14, No.1, pp.20-30.

Aubert-Gamet V. and Cova, B. (1999), 'Servicescapes: From Modern non-places to Post-modern Common-places', Journal of Business Research, Vol. 44, No.1, pp. 37-45.

Badot, O., Bucci, A. and Cova, B. (1993), 'Societing: Managerial Response to European Aestheticization', European Management Journal, Special Issue, EAP $20^{\text {th }}$ Anniversary, pp. 48-55. 
Ball, A. and Tasaki, L. (1992), 'The Role and Measurement of Attachment in Consumer Behaviour' Journal of Consumer Psychology, Vol.1, No.2, pp. 155-172

Balmer J., and Greyser, S., (2006), 'Corporate Marketing : Commentary - Integrating Identity, Corporate Branding, Corporate Communications, Corporate Image and Corporate Reputation', European Journal of Marketing, Vol 40, No 7/8, pp. 730-741.

Balmer J., and Gray. E., (2003), 'Corporate brands; what are they? What of them,', European Journal of Marketing, Vol 37, No 7/8, pp. 972-997

Bennett, R., (1997), 'Corporate Philanthropy in UK: Altruistic Giving or Marketing Communications Weapon?', Journal of Marketing Communications, No.3, pp. 87-109

Bhattarachya, C.B., Rao, H., and Glynn, M., (1995), 'Understanding the Bonds of Identification : An Investigation of its Correlates among Art Museum Members', Journal of Marketing, Vol 59, pp. 46-57.

Brewer, Marilynn, B. and Wendi Gardner (1996), 'Who is This "We"? Levels of Collective Identity and Self-Representations,' Journal of Personality and Social Psychology, Vol 71, pp. 83-93.

Bromley D., (2001), 'Relationships between personal and corporate reputation', European Journal of Marketing, Vol 35, No 3.4, pp. 316-334.

Cheney G. and Tomkins, P., (1987), 'Coming to terms with organizational identification and commitment', central States Speech Journal, Vol 38, pp 1-15.

Christensen L., and Askegaard, S., (2001), 'Corporate Identity and Corporate Image Revisited', European Journal of Marketing, Vol 35, No 3/4, pp. 293-315.

Collins, M. (1994), 'Global Corporate Philanthropy and Relationship Marketing' European Management Journal, Vol.12, No.2, pp. 226-33

Cornwell, T. B., and Maignan, I. (1998), 'An International Review of Sponsorship Research', Journal of Advertising, Spring 98, Vol. 27, Issue 1, p. 1

Cova, B. (1999), 'From Marketing to Societing: When the Link is More Important than the Thing' In: Brownlie, D., Saren, M., Wensley, R. and Whittington, R. (Eds), Rethinking Marketing, Sage, London, pp. 64-83

Cova, B. and Cova, V.(2002), 'Tribal Marketing: The Tribalisation of Society and its Impact on the Conduct of Marketing', European Journal of Marketing, Vol. 36, No. 5/6, pp. 595-620

Dolphin, R. (2003), 'Sponsorships: Perspectives on its Strategic Role', Corporate Communications: An International Journal, Vol. 8, No. 3, pp. 173-186

Dutton, J., Dukerich, J., and Harquail, C., (1994), 'Organizational images and member Identification',Administrative Science Quarterly, Vol 39, pp. 239-263.

Ellemers, N., Kortekaas, P. and Ouwerkerk, J., (1999), 'Self-categorisation, Commitment to the Group and Group Self-Esteem as Related but Distinct Aspects of Social Identity', European Journal of Social Psychology, Vol 29, pp. 371-389

Erickson, G. and Kushner, R. (1999), 'Public Event Networks: An Application of Marketing Theory to Sporting Events', European Journal of Marketing, Vol. 33, No. 3/4, pp. 348-364

Fahy, J., Farrelly, F. and Quester, P. (2004), 'Competitive Advantage through Sponsorship: A Conceptual Model and Research Propositions', European Journal of Marketing, Vol. 38, No. 8, pp. 1013-1030

Farrelly, F. and Quester, P. (2003),, 'The Effects of Market Orientation on Trust and Commitment: The Case of the Sponsorship Business-to-business Relationship', European Journal of Marketing, Vol. 37, No 3/4, pp. 530-553 
Feyerabend, P. (1981), Philosophical Papers: Vol. 1, Realism, rationalisation and scientific method,. Cambridge.

Geyskens, I. and Steenkamp, J., (1995), 'An Investigation into the Joint Effects of Trust and Interdependence on Relationship Commitment', In Bregadaa (Ed), Proceedings of the $24^{\text {th }}$ EMAC Conference, ESSEC. Cergy-Pontoise

Goulding, C. (2001) Grounded Theory: A Magical Formula or a Potential Nightmare, The Marketing Review, Vol 2, pp. 21-34

Gray J., (1986), Managing the Corporate Image: Key to Public Trust, Quorum Books, Westport, CT.

Gregory, A., (2007), Involving stakeholders in developing Corporate Brands: the Communication Dimension, Journal of Marketing Management, Vol 23, No 1-2, pp 59-73.

Greyser, S., (1997), Janus and Marketing, Reflections on the future of Marketing, Marketing Science Institute, Boston MA.

Grimes, E. and Meenaghan, T. (1998), 'Focusing Commercial Sponsorship on the Internal Corporate Audience', International Journal of Advertising, Vol. 17, No. 1, pp. 51-74

Gwinner, K. and Swanson, S., (2003), 'A Model of Fan Identification: Antecedents and Sponsorship Outcomes', Journal of Services Marketing, Vol. 17, No. 3, pp. 275-294.

Haigh, J. and Crowther, G. (2005), 'Interpreting Motorcycling Through its Embodiment in Life Story Narratives', Journal of Marketing Management, Vol. 21, pp. 555-572.

Harrison, D.A., Price, K.H., Gavin, J.H., Florey, A.T. (2002), 'Time, teams, and task performance: changing effects of surface- and deep-level diversity on group functioning', The Academy of Management Journal, Vol. 45 pp.1029-45.

Haslam, S. A., and Turner, J. C. (1992). 'Context-dependent variation in social stereotyping 2: The relationship between frame of reference, self-categorization and accentuation'. European Journal of Social Psychology, Vol 22, pp. 251-277.

Hoek, J. and Gendall, P., (2003), 'How Does Sponsorship Work?', ANZMAC Conference Proceedings Adelaide, $1-3^{\text {rd }}$ December

Hogg, M. and Turner, J. (1985), 'Interpersonal Attraction, Social Identification and Psychological Group Formation', European Journal of Social Psychology, Vol. 15, pp. 51-66

Hunt, K., Bristol, T. and Bashaw, E. (1999), 'A Conceptual Approach to Satisfying Sports Fans', Journal of Services Marketing, Vol. 13, No.6, pp. 439-52

IMP, Group. (1982), 'International Marketing and Purchasing of Industrial Good'. In D. Ford (Ed.), Understanding Business Markets: Interactions, Relationships and Networks, pp.1027. London: Academic Press.

Kay, M., (2006), 'Strong Brands and Corporate Brands', European Journal of Marketing, Vol 40, No 7/8, pp. 742-760.

Knox S. and Bickerton D., (2003), 'The six conventions of corporate branding', European Journal of Marketing, Vol 37, No 7/8, pp. 998-1016.

Lings I., and Owen K., (2007), Buying the sponsor's brand: the role of affective commitment to the sponsored team, Journal of Marketing Management, Vol 23, No 5-6, pp 483-496.

Mack, R., (1999), 'Event Sponsorship: An Exploratory Study of Small Business Objectives, Practices and Perceptions', Journal of Small Business Management, Vol. 37, No. 3, pp. $25-30$

McCracken, G. (1988), The Long Interview, SAGE Publications Ltd, London, England. Cited in Arksey, H. and Knight, P. (1999), Interviewing for Social Scientists, SAGE Publications Ltd, London, England 
Meenaghan, T., (1991), 'The Role of Sponsorship in the Marketing Communications Mix', International Journal of Advertising, , Vol.10, No.1, pp.3-28

Melewar, T., and Karaosmanoglu, E., (2006), 'Seven Dimensions of Corporate Identity', European Journal of Marketing, Vol 40, No 7/8, pp. 846-869.

Moingeon, B., and Ramanantsoa, B., (1997), 'Understanding corporate identity : the French school of thought', European Journal of Marketing, Vol 31, No 5, pp. 383-395.

Moutinho, L., Dionisio, P. and Leal, C. (2007), 'Surf Tribal Behaviour: A Sports Marketing Application', Marketing Intelligence and Planning, Vol. 25, No.7, pp. 668-690

Olkkonen, R. and Tuominen, P. (2006), 'Understanding Relationship Fading in Cultural Sponsorships', Corporate Communications: An International Journal, Vol. 11, 1, pp. 64-77

Polonsky, M. and Speed, R. (2001), 'Linking Sponsorship and Cause Related Marketing: Complementarities and Conflicts', European Journal of Marketing, Vol. 35, No. 11/12, pp. 1361-1385

Popper, K. (1965), Conjectures and Refutations: The growth of scientific knowledge.

New York: Harper and Row.

Pratt and Foreman, (2000), 'Classifying managerial responses to multiple organizational identities', Academy of Management Review, Vol 25, No 1, pp. 18-49.

Real and Mechikoff (1992), 'Deep Fan: Mythic Identification, Technology and Advertising in Spectator Sports', Sociology of Sport Journal, Vol. 9, pp. 323-39.

Remenyi, D., Williams, B., Money, A. and Swartz, E. (1998), 'Doing Research in Business and Management: An introduction to Process and Method', Sage Publications, London, UK

Saunders J., Lewis and Thornhill, (2007), 'Research Methods for Business Students', Pearson Education Ltd.

Spiggle, Susan (1994), 'Analysis and Interpretation of Qualitative Data in Consumer Research,' Journal of Consumer Research, Vol 21(December), pp. 491-503.

Strauss A. and Corbin J. (1990), 'Basics of Qualitative Research : grounded theory procedures and techniques', London, Sage Publications.

Suvatjis, J.S., de Chernatony, L., (2005), Corporate Idenity Modelling: a Review and Presentation of a new Multidimensional Model, Journal of Marketing Management, Vol 21, No 7-8, pp 809-834.

Tajfel H. and Turner J., (1986), 'The Social Identity Theory of Intergroup Behaviour', in S. Worchel and W.G. Austin, (Eds) Psychology of Intergroup Relations, pp. 7-24, Chicago, Nelson.

Theofilou, A., Ventoura-Neokosmidi, Z. and Neokosmidis, I. (2007), 'Measuring Sponsorship Effects on Consumer Purchasing Intentions', Proceedings of the Oxford Business and Economics Conference, June $24^{\text {th }}-26^{\text {th }}$, ISBN: 978-0-9742114-7-3

Thwaites, D., Aguilar-Manjarrez, R. and Kidd, C. (1998), 'Sports Sponsorship Development in Leading Canadian Companies: Issues and Trends' International Journal of Advertising, Vol. 17, (1), pp. 29-49

Topalian, A., (2003), 'Experienced Reality, the Development of Corporate Identity in the Digital Era', European Journal of Marketing, Vol 37, No 7/8, pp. 1119-1132.

Tripodi, J. (2001), 'Sponsorship- A Confirmed Weapon in the Promotional Armoury', International Journal of Sports Marketing and Sponsorship, Vol 14, March/April

Turner, J. (1987), 'A self-categorization theory', in M. Hogg P. Oakes, S. Reicher and M. Wetherell, (Eds), Rediscovering the Social group : a Self-categorization theory, 42-67, Oxford, Blackwell. 
Walliser, B. (2003), 'An International Review of Sponsorship Research: Extension and Update' International Journal of Advertising, Vol. 22, No.1, pp. 1-27

Wetzels, M. De Ruter, K. Birgelen, M. V. (1998), 'Marketing Service Relationships: The Role of Commitment', The Journal of Business and Industrial Marketing, 1998, Vol 13, No. 4, pp. 405-423

Zillman, D., Byrant, J. and Sapolsky, N. (1989), 'Enjoyment from Sports Spectatorship', in Goldstein, J. (Ed), Sports, Games and Play, Laurence Erlbaum, Hillsdale, NJ, pp. 241-278

\section{Table 1 : Mutuality in sponsor-relationships}

\begin{tabular}{|ll|}
\hline R2 & All decisions are based on trust. .... Reduces time wastage on checking and auditing \\
R5 & Trust speeds up decision making \\
R6 & Without trust you waste time which you should be spending on what you are paid to do \\
R7 & $\begin{array}{l}\text { Most decisions [and generation of trust] are made at the start of the relationship. } \\
\text { R8 }\end{array}$ \\
$\begin{array}{l}\text { The degree [of decision-making certainty] varies with the trust and importance of the } \\
\text { relationship }\end{array}$
\end{tabular}


Table 2: Profile and Sponsorship Motivation of Respondents 


\begin{tabular}{|c|c|c|c|c|}
\hline $\begin{array}{l}\text { Respondent } \\
\text { And } \\
\text { Position }\end{array}$ & $\begin{array}{l}\text { Context of } \\
\text { Sponsorship } \\
\text { Involvement }\end{array}$ & $\begin{array}{l}\text { Organisational } \\
\text { Profile }\end{array}$ & $\begin{array}{l}\text { Primary Sponsorship } \\
\text { Objective }\end{array}$ & Evaluation of Sponsorship \\
\hline $\begin{array}{l}\text { R1 } \\
\text { Managing } \\
\text { Director }\end{array}$ & $\begin{array}{l}\text { Five years } \\
\text { Known for } \\
\text { Superbike } \\
\text { sponsorship- } \\
\text { close } \\
\text { relationships } \\
\text { with sponsees }\end{array}$ & $\begin{array}{l}\text { SME design } \\
\text { and construction } \\
\text { of swimming } \\
\text { pools within the } \\
\text { UK and Europe }\end{array}$ & $\begin{array}{l}\text { Through corporate } \\
\text { hospitality, to gain closer } \\
\text { relationships by taking } \\
\text { business relationships 'out of } \\
\text { standard work-related } \\
\text { environments into something } \\
\text { enjoyable to both parties'. }\end{array}$ & $\begin{array}{l}\text { Assesses whether relationships } \\
\text { between co. and target companies } \\
\text { are maintained/ improved. Expect } \\
\text { returns on investment between } 0 \text { - } \\
18 \text { months On-track success not } \\
\text { an objective, but an advantage. } \\
\text { Annual verbal agreements }\end{array}$ \\
\hline $\begin{array}{l}\text { R2 } \\
\text { Head of } \\
\text { Customer } \\
\text { Strategy }\end{array}$ & $\begin{array}{l}\text { Five years } \\
\text { Interested in } \\
\text { long term } \\
\text { relationships } \\
\text { Seeks the 'right' } \\
\text { sponsorship }\end{array}$ & $\begin{array}{l}\text { Multi-national } \\
\text { commercial } \\
\text { vehicle } \\
\text { manufacturer }\end{array}$ & $\begin{array}{l}\text { Aim to generate the 'right' } \\
\text { sponsorship. To utilise } \\
\text { hospitality facilities, } \\
\text { provided by the sponsee, to } \\
\text { speak to fleet customers, in } \\
\text { an out-of-work environment }\end{array}$ & $\begin{array}{l}\text { Benefits expected are 'slow burn' } \\
\text { - about building relationships } \\
\text { with their stakeholders. On track } \\
\text { success important but not } \\
\text { necessary to achieve goals. } \\
\text { Contracts negotiated annually and } \\
\text { increasingly formal and written }\end{array}$ \\
\hline $\begin{array}{l}\text { R3 } \\
\text { International } \\
\text { Racing } \\
\text { Director }\end{array}$ & $\begin{array}{l}\text { Thirteen years } \\
\text { Close } \\
\text { involvement in } \\
\text { motorsport- } \\
\text { Seek to contract } \\
\text { factory teams } \\
\text { sponsorship } \\
\end{array}$ & $\begin{array}{l}\text { Multi-national } \\
\text { tyre } \\
\text { manufacturer }\end{array}$ & $\begin{array}{l}\text { Raising brand profile and } \\
\text { product development. } \\
\text { Partner with Superbike } \\
\text { series organizers. Seeks to } \\
\text { view to increase top-team } \\
\text { competitors using tyres and } \\
\text { gain global exposure. }\end{array}$ & $\begin{array}{l}\text { Belief - benefits are secured over } \\
\text { many seasons. Offers substantial } \\
\text { cost saving - Relationships are } \\
\text { formalised through written } \\
\text { contracts. Maintain a four-five } \\
\text { year, annually assessed, } \\
\text { sponsorship plan }\end{array}$ \\
\hline $\begin{array}{l}\text { R4 } \\
\text { Rider } \\
\text { Representati } \\
\text { ve }\end{array}$ & $\begin{array}{l}\text { Eleven years } \\
\text { Former rider } \\
\text { Respondent is } \\
\text { prominent in } \\
\text { British } \\
\text { Superbike }\end{array}$ & $\begin{array}{l}\text { Business is } \\
\text { sponsorship, } \\
\text { rider, team } \\
\text { management } \\
\text { Representative } \\
\text { for no. of top } \\
\text { Superbike riders } \\
\end{array}$ & $\begin{array}{l}\text { Primarily to achieve on-track } \\
\text { success - aid in form of rider } \\
\text { management, financial } \\
\text { support, loans of recoverable } \\
\text { assets - race machinery. } \\
\text { Equally notes associated } \\
\text { emotional pleasure }\end{array}$ & $\begin{array}{l}\text { Setting benchmarks in the form of } \\
\text { predictions. Contracts are verbal } \\
\text { and informal as will only support } \\
\text { those he trusts and has a current } \\
\text { relationship with. }\end{array}$ \\
\hline $\begin{array}{l}\text { R5 } \\
\text { National } \\
\text { Marketing } \\
\text { Manager }\end{array}$ & $\begin{array}{l}\text { Thirteen years } \\
\text { Sponsored } \\
\text { Superbike in } \\
\text { early days. Sees } \\
\text { presence as } \\
\text { important to } \\
\text { brand building }\end{array}$ & $\begin{array}{l}\text { SME } \\
\text { manufacturer of } \\
\text { motorcycle } \\
\text { security and } \\
\text { touring products } \\
\text { for domestic and } \\
\text { export markets }\end{array}$ & $\begin{array}{l}\text { Hospitality activities- } \\
\text { corporate reputation building } \\
\text { - to create awareness of the } \\
\text { products they distribute to } \\
\text { the end-customers. To build } \\
\text { intermediary confidence }\end{array}$ & $\begin{array}{l}\text { Sees benefits, (smooth working } \\
\text { relationships with intermediaries) } \\
\text { increase - each year of BSB } \\
\text { sponsorship adds value to last. } \\
\text { Sponsorship agreements are } \\
\text { seasonal but relationships fostered } \\
\text { last longer. Agreements supported } \\
\text { by written contracts }\end{array}$ \\
\hline $\begin{array}{l}\text { R6 } \\
\text { Motorsports } \\
\text { Manager }\end{array}$ & $\begin{array}{l}\text { Seven years } \\
\text { Targets young } \\
\text { riders } \\
\text { Works with } \\
\text { Honda racing. } \\
\text { Ambitious - and } \\
\text { hope to find } \\
\text { next British } \\
\text { Champion } \\
\end{array}$ & $\begin{array}{l}\text { Global energy } \\
\text { drink } \\
\text { manufacturer }\end{array}$ & $\begin{array}{l}\text { Raising brand awareness, } \\
\text { used when brand launched in } \\
\text { UK initially and continued } \\
\text { Media value of brand } \\
\text { association. Aim - nurturing } \\
\text { young talent - link to brand } \\
\text { values of innovation Long- } \\
\text { term goal = mutual bonding } \\
\text { Access to corporate hospital. }\end{array}$ & $\begin{array}{l}\text { Benefits expected over long-term. } \\
\text { Commitment stronger with riders } \\
\text { rather than team- aids progression } \\
\text { of promising riders (selective). } \\
\text { Rider success and on track victory } \\
\text { basis for sponsorship evaluation. } \\
\text { Have 3-year written contract with } \\
\text { Honda, and intend to continue the } \\
\text { relationship if satisfied }\end{array}$ \\
\hline $\begin{array}{l}\text { R7 } \\
\text { Team } \\
\text { Manager }\end{array}$ & $\begin{array}{l}\text { Six years } \\
\text { Former rider. } \\
\text { Trained coach in } \\
\text { motorcycling } \\
\text { racing. Supports } \\
\text { three riders }\end{array}$ & $\begin{array}{l}\text { Set up and runs } \\
\text { a three class } \\
\text { team - link to } \\
\text { Honda }\end{array}$ & $\begin{array}{l}\text { Objectives are primarily } \\
\text { personal and philanthropical. } \\
\text { Access to corporate } \\
\text { hospitality packages - riders } \\
\text { expected to entertain } \\
\text { sponsors who support his } \\
\text { racing activities }\end{array}$ & $\begin{array}{l}\text { Immediate benefits expected }= \\
\text { sponsor satisfaction. Long-term }= \\
\text { networking and return in form of } \\
\text { goodwill. Sponsorship } \\
\text { agreements verbal and seasonal - } \\
\text { but relationship is continual. }\end{array}$ \\
\hline $\begin{array}{l}\text { R8 } \\
\text { Marketing } \\
\text { Director }\end{array}$ & $\begin{array}{l}\text { Six years } \\
\text { Formerly close } \\
\text { involvement } \\
\text { with team }\end{array}$ & $\begin{array}{l}\text { Holding } \\
\text { company }\end{array}$ & $\begin{array}{l}\text { Strong philanthropical goals. } \\
\text { Association of brand with } \\
\text { motorcycle race team gives } \\
\text { exposure - branding benefits } \\
\text { by association - image of fast } \\
\text { moving cutting edge } \\
\text { company. Access to } \\
\text { corpolate entertainment. }\end{array}$ & $\begin{array}{l}\text { Assesses feedback on hospitality } \\
\text { events - Commitment dependent } \\
\text { on return. Benefits over long- } \\
\text { term, intention to 'stay for the } \\
\text { duration'. Sponsorships } \\
\text { supported by legally binding } \\
\text { contracts. }\end{array}$ \\
\hline
\end{tabular}


